\title{
"Modernization of social dialogue as an imperative for developing social responsibility by business organizations in Ukraine"
}

\begin{tabular}{|c|c|}
\hline \multirow{8}{*}{ AUTHORS } & Halyna Lopushniak (I) https://orcid.org/0000-0001-8576-6440 \\
\hline & \\
\hline & Yurii Marshavin (D https://orcid.org/0000-0003-0144-1441 \\
\hline & R http://www.researcherid.com/rid/L-1120-2018 \\
\hline & Taras Kytsak (D https://orcid.org/0000-0002-0525-7556 \\
\hline & R http://www.researcherid.com/rid/K-7699-2018 \\
\hline & Olena lastremska (D https://orcid.org/0000-0002-5653-6301 \\
\hline & Yurii Nikitin (D http://orcid.org/0000-0002-5566-8943 \\
\hline ARTICLE INFO & $\begin{array}{l}\text { Halyna Lopushniak, Yurii Marshavin, Taras Kytsak, Olena lastremska and Yurii } \\
\text { Nikitin (2021). Modernization of social dialogue as an imperative for developing } \\
\text { social responsibility by business organizations in Ukraine. Problems and } \\
\text { Perspectives in Management, 19(1), 487-498. doi:10.21511/ppm.19(1).2021.41 }\end{array}$ \\
\hline DOI & http://dx.doi.org/10.21511/ppm.19(1).2021.41 \\
\hline RELEASED ON & Monday, 05 April 2021 \\
\hline RECEIVED ON & Tuesday, 05 January 2021 \\
\hline ACCEPTED ON & Wednesday, 31 March 2021 \\
\hline & $(\mathrm{ccc})$ EY \\
\hline LICENSE & $\begin{array}{l}\text { This work is licensed under a Creative Commons Attribution } 4.0 \text { International } \\
\text { License }\end{array}$ \\
\hline JOURNAL & "Problems and Perspectives in Management" \\
\hline ISSN PRINT & $1727-7051$ \\
\hline ISSN ONLINE & $1810-5467$ \\
\hline PUBLISHER & LLC "Consulting Publishing Company "Business Perspectives" \\
\hline FOUNDER & LLC "Consulting Publishing Company "Business Perspectives" \\
\hline$\sigma^{\circ}$ & 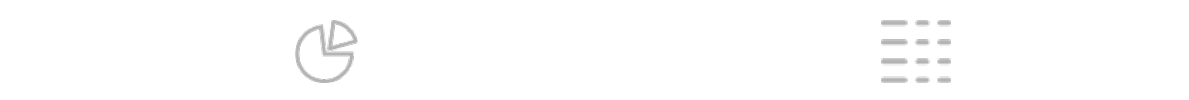 \\
\hline NUMBER OF REFERENCES & NUMBER OF FIGURES \\
\hline 31 & 0 \\
\hline
\end{tabular}

(C) The author(s) 2023. This publication is an open access article. 


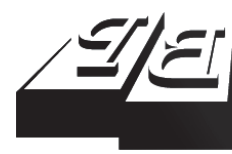

BUSINESS PERSPECTIVES

()

LLC "CPC "Business Perspectives" Hryhorii Skovoroda lane, 10, Sumy, 40022, Ukraine www.businessperspectives.org

Received on: $5^{\text {th }}$ of January, 2021 Accepted on: $31^{\text {st }}$ of March, 2021 Published on: $5^{\text {th }}$ of April, 2021

(c) Halyna Lopushniak, Yurii Marshavin Taras Kytsak, Olena Iastremska, Yurii Nikitin, 2021

Halyna Lopushniak, Doctor of Economics, Professor, Head of the Personnel Management and Labor Economics Department, Kyiv National Economic University named after Vadym Hetman, Ukraine.

Yurii Marshavin, Doctor of Economics, Professor, Personnel Management and Labor Economics Department, Kyiv National Economic University named after Vadym Hetman, Ukraine.

Taras Kytsak, Ph.D. in Economics, Associate Professor, Personnel Management and Labor Economics Department, Kyiv National Economic University named after Vadym Hetman, Ukraine. (Corresponding author)

Olena Iastremska, Doctor of Economics, Professor, Head of the Department of Management, Logistics and Innovations, Simon Kuznets Kharkiv National University of Economics, Ukraine.

Yurii Nikitin, Doctor of Historical Sciences, Associate Professor, Rector, Sumy Regional Institute of Postgraduate Pedagogical Education, Ukraine.
Halyna Lopushniak (Ukraine), Yurii Marshavin (Ukraine), Taras Kytsak (Ukraine), Olena Iastremska (Ukraine), Yurii Nikitin (Ukraine)

\section{MODERNIZATION OF SOCIAL DIALOGUE AS AN IMPERATIVE FOR DEVELOPING SOCIAL RESPONSIBILITY BY BUSINESS ORGANIZATIONS IN UKRAINE}

\begin{abstract}
The relevance of the paper is determined by the need to modernize social dialogue in Ukraine as a means of increasing the social responsibility of business organizations and a prerequisite for the country's sustainable socio-economic development. The paper is aimed at reviewing and systematizing effective practices of modernization of social dialogue, which are revealed in the publications of foreign and Ukrainian scientists, high-ranking officials and public figures. These practices are considered from the standpoint of their expediency and the possibility of their implementation in the processes of social interaction of organizations of employees, employers and public authorities in Ukraine.
\end{abstract}

A review of the foreign experience in organizing social dialogue convincingly demonstrates a fairly high level of efficiency in the European Union, which contributes to achieving a balance of interests of major economic actors, increasing their social responsibility. For Ukraine, it is expedient to introduce the European practice of the so-called broad approach to the organization of social dialogue, which provides for the expansion of its subjects at the expense of representatives of territorial entities, environmental, women's, youth, cultural and other public organizations. The involvement of local governments, public and NGOs in solving the most important socio-economic problems will contribute to the spread of the practice of differentiating between social and public dialogue. In Ukraine, employee participation in corporate governance should be strengthened, access to shareholder income should be expanded, and institutional tools for regulating the collective bargaining process should be improved.

Keywords

state, dialogue, stakeholders, development, sustainability, responsibility, partnership, sustainable development

\section{JEL Classification J08, A13, L14, M14, Z13}

\section{INTRODUCTION}

The development of modern civilization is characterized not only by dynamic technical and technological progress, gradual improvement of social and labor relations, but also the growing contradictions between labor and capital, a partial return to the liberal ideas of the era of "wild" capitalism. Socio-economic realities require new approaches to ensuring sustainable social development, development of opportunities, prospects and tools to overcome potential risks. The activities of a business organization can no longer be limited to job creation, production of material values and making profits. Businesses, as key actors in the social, economic and environmental spheres of society, must develop new ways to rationally combine the achievement of the maximum level of profitability and meet the demands and needs of key social stakeholders. The implementation of the concept of corporate social responsibility in business practice is becoming an effective tool to achieve these goals. 
Corporate social responsibility is based on the idea that the contradiction between the personal interest of business (profit) and the interests of society (stability, employment, decent work, successful development for the majority) should be addressed by business structures for the benefit of society as a whole as a system, of which business organizations are an integral part. However, the achievement of such results is possible only with the formation of a socially responsible environment under the influence of active institutional actions of social dialogue and partnership between the state, business and civil society institutions.

Social responsibility as an integral social phenomenon can exist only under the condition of a socially responsible state and socially responsible activities of business, civil society institutions and all citizens. The most effective factor in its development is social dialogue, when, through the instrumental action of social partnership, the government, trade unions and employers' organizations adhere to ethical principles, fulfill additional voluntary commitments aimed at human capital development, competitiveness of companies and the national economy as a whole. Social dialogue plays an important role due to balanced political and economic decisions in the process of negotiations, constructive interactions and partnerships between the parties. The implementation of the main ideas of sustainable development will be more effective due to the modernization of social dialogue as the main platform that contributes to the interests and needs of the main social actors.

\section{LITERATURE REVIEW}

The initial stage in the formation of social dialogue on a global scale is 1919 - the year of the founding of the International Labor Organization, whose activities were based on the principles of tripartism, that is, a partnership between government, employers and employees aimed at establishing minimum labor standards by adopting conventions and recommendations.

According to the International Labor Organization, social dialogue is a process that involves the participation of employees, employers and the government in the decision-making process in the field of employment related to problems arising in the workplace. It includes all types of negotiations, consultations and exchange of information by representatives of these groups in relation to common interests in the field of socio-economic and labor policies. Social dialogue is also a means of ensuring socio-economic progress and the purpose of these processes, since it allows the above entities to express their aspirations and defend their interests, to achieve mutual understanding when making agreed decisions.

Social dialogue is a characteristic feature of the process of convergence of interests, reaching joint agreements and making agreed decisions by entities representing the interests of employees, em- ployers, executive authorities and local governments on the formation and regulation of social and labor relations.

International experience in the development of social dialogue is based on its systematic institutionalization and implementation of sustainable development goals through partnerships with the participation of many parties. The final document on the 2030 Agenda for Sustainable Development calls for the encouragement of effective partnerships between public organizations and the private sector, as well as between civil society organizations, drawing on the experience and strategies of using partners' resources. The International Labor Organization declares the idea that dialogue and tripartism are the most promising ways to ensure sustainable development and to respond to ever-changing labor challenges. One of the main tools for sustainable development should be social dialogue, which will be based on traditional and new forms of cooperation between governments, employees' and employers' organizations, between the public, private sectors and civil society organizations to maximize the quality of people's life both today and in the future, while ensuring economic, social and environmental sustainability on the planet (Social Dialogue. Report, 2013).

Social dialogue can function effectively under the following conditions: the presence of powerful, 
independent organizations of employers and employees with the necessary quality potential and up-to-date information; political will and interest of the parties in participating in social dialogue; respect for the fundamental rights to freedom of association and collective bargaining; obligatory fulfillment by each party of the dialogue of the obligations assumed; favorable legal and institutional environment (Social Dialogue. Report, 2013).

Significant advances in the use of social dialogue have been accumulated primarily in the European Union (Kolot, 2013a). In 1985, the European Commission significantly improved the concept of social dialogue after the adoption of the Single European Act, according to which the Commission formally committed itself to the further development of social dialogue (Consolidated versions of the Treaty on European Union and the Treaty on the Functioning of the European Union, 2012). Social dialogue is implemented at inter-sectoral and sectoral levels in consultation processes led by the European Commission and at the level of individual negotiation processes, which contributes to developing social responsibility of all actors. The Social Dialogue Committee is the main player at the inter-sectoral level. It is composed of 32 representatives from European social partners, chaired by the European Commission. Employees are represented by the European Trade Union Confederation (ETUC), employers - by three associations such as the Confederation of European Business (BUSINESSEUROPE), the European Centre of Employers and Enterprises providing Public Services (CEEP), and the European Association of Craft, Small and Medium-Sized Enterprises (UEAPME) (Social Dialogue. A manual for trade union education, 2012, p. 28).

The main direction of the development of the European social dialogue is the signing agreements on social partnership. In practice, they are implemented in two main ways. In the first case, the social partners ask the Commission to give the agreement the status of a directive, which, once adopted by the Council, acquires this status. Another way is that the social partners implement the agreement independently, which, in turn, obliges the national social partners to comply with the provisions of the agreement in all countries that are members of the European Union (Social
Dialogue. A manual for trade union education, 2012, p. 28).

The European social dialogue gained new momentum in March 2003 with the convening of a tripartite social summit on economic growth and employment. It was attended by representatives of the Council, Commission, and European social partners. In general, the European experience demonstrates a progressive example of the ability to achieve a balance of interests of the main state actors, which positively affects the development of their social responsibility. Sweden is an example of successful implementation of the concept of tripartite cooperation. The regulation of the labor market, wages and working conditions in the Swedish welfare state model is based on a high level of willingness to negotiate and compromise in finding a balance between flexibility and job security (ILO, 2016, November 21).

Social dialogue should take the form of discussion, consultation, negotiation and joint concerted action with actors representing the interests of employers and workers. In practice, it is implemented in the form of a tripartite dialogue with the participation of state bodies and a bilateral dialogue between European employers and trade unions. These forms are also applied at the sectoral and intersectoral level. Financial support is provided for transnational projects carried out with the participation of social partners and other industrial relation actors on various infrastructure platforms of social dialogue. The European Social Fund also provides support to rebuild the capacity of the social partners at the national level (Kolot, 2013a).

The common fundamental values of the European social model (Deutsche Welle, n.d.) are formulated: commitment to democracy, non-discrimination, universal access to education, high-quality and universal health care, gender equality, solidarity and justice, recognition of the role of social partners and social dialogue. Focusing on these values helps European employers' associations, trade unions and governments make significant progress in promoting social responsibility.

Sapir (2002) identifies four models of social dialogue in Europe: Northern European, AngloSaxon, Continental, and Southern Mediterranean. 
Each of them has its own characteristics. In the Nordic countries, the dominant role is played by states that are guided by the principles of equality and solidarity in the field of social security, which is characterized by a high level of both taxation and social benefits. The Anglo-Saxon model is characterized by liberal approaches to the formation of a social protection system and partnership in organizing social dialogue. The continental type is also formed according to liberal principles in matters of social partnership, the development of insurance funds at the expense of employers, and the active role of trade unions. The Mediterranean model is characterized by the role of civil society in shaping the environment for social dialogue.

In recent years, the idea of a so-called broad approach to organizing social dialogue has been gaining momentum in Europe, which consists in expanding the range of its subjects at the expense of representatives of territorial entities, environmental, women's, youth, cultural, and other public organizations, other state and non-state institutions (Social dialogue in Ukraine in the context of signing an association agreement - challenges and proposals: draft, 2014).

In Ukraine, the main form of social dialogue was the holding joint meetings, conferences and other events at the national, sectoral and regional levels. But, as rightly noted in the Decent Work Program of the International Labor Organization for Ukraine for 2016-2019, government bodies and employers, as a rule, independently, without the participation of employees and their representative organizations, determine the content of decisions in this area, and if consultations, then purely formal (Verner, 2019). Public authorities, employers' organizations, trade unions, and social dialogue bodies at the national level have distanced themselves from the pressing problems in the social and labor sphere and transferred them to the enterprise level, which led to a weakening of social responsibility and increased exploitation of employees. The result was a serious decline in real wages, which in euros remains one of the lowest in Europe, stimulating the outflow of the economically active population into shadow employment and work abroad; a constant reduction of the average number of full-time employees: in 2014 there were 8,959 thousand, in $2018-7,662$ thousand people, or $14.5 \%$ less (Verner, 2019). At the same time, labor passivity is growing among the population: according to estimates, the total unused labor reserve in the registered segment of the domestic labor market is at least 10 million people. Negative tendencies in the socio-economic policy of Ukraine are also aggravated by non-compliance with the principles of civil society, the removal of its institutions from participation in solving acute socio-economic problems. Social dialogue has not reached the proper level and has not become a real means of increasing the social responsibility of government, business organizations: its current model severely limits and often excludes employees and their representatives from the decision-making process in the social sphere (Verner, 2019).

Distortion of the principles of social dialogue, which are defined in the legislation in Ukraine, creates a significant obstacle to the interaction of state authorities, trade unions and business organizations (Robotodavets, n.d.). First of all, it is about a fundamental principle such as independence and equality of the parties. In fact, at all levels of tripartism (national, regional, and sectoral), the social dialogue is actually dominated by the state, and at the dual level (enterprise) by employers. In particular, this confirms the procedure for the formation of the National Tripartite Social and Economic Council (hereinafter, NTSEC), which includes representatives of the government, representative organizations of workers and employers. The analysis shows that it is not an independent institution and does not play a more or less noticeable role in socio-economic policy, since it is created by the President of Ukraine, who appoints its secretariat - in fact the executive body of NTSEC. The same is the case with similar bodies at the regional level, which create regional state administrations, turning other parties into executors of local government decisions, and social dialogue bodies into a kind of democratic facade that reduces the social responsibility of local authorities.

Focusing on the fundamental interests of the economically active population, the analysis of the problem of social dialogue partners in Ukraine shows the need to involve very important subjects of social and labor relations in its circle, which for various reasons remain outside the contractual 
process. It is necessary to agree with the ideas of the ILO experts, who drew the attention of government circles and the public of Ukraine to the fact that the existing social dialogue bodies do not reflect the interests of many economic entities: non-representative organizations of employees and employers, as well as entrepreneurs and small business employees, self-employed persons, representatives of the informal sector of the economy, other categories of economically active population not united in legal organizations (Social dialogue. Report, 2013).

The modernization of social dialogue as an effective tool for the development of social responsibility should take place in the direction of strengthening government interaction with social partners and civil society institutions (associations, NGOs, independent experts, local authorities and local activists) to discuss issues and define a program of joint actions. Involving all stakeholders in public communications will help agree on a road map for modernizing social dialogue (Kolot, 2013a; Kolot et al., 2020).

Thus, social dialogue is an important factor in the development of social responsibility and management of sustainable social development, which, above all, should move in the following areas: the concept of decent work, gender equality, social development, introduction of innovative technologies, and economical use of environmental resources. These main directions of sustainable development of society will be qualitatively implemented, subject to their implementation in the practice of business organizations, which should play an increasingly important role in the management of society.

The corporations are responsible for realizing the constitutional Americans' rights - "ensuring the inalienable right to life, liberty, personal development, and well-being." The task of management is to manage the impact of the institution on society with the means and instruments of social responsibility. None of the institutions exists in itself and is not an end in itself. Each institution is a social structure that must function for the sake of society and its interests. The business sector is no exception. Entrepreneurship should benefit not only business, but society as well.
Scientific interpretations of the social responsibility of business organizations and their impact on society were developed by Bowen (1953), who in 1953 defined its essence, namely, businessmen should adhere to such policies, make such decisions and develop such behavior that is most desirable, given the goals and values of society. Davis (1960) also made a significant contribution to the formation of the ideology of business organizations' social responsibility, proposing the idea of a comprehensive approach to the influence of external actors that determine the social activity of business organizations. His research substantiates a number of unshakable provisions that influenced the theoretical foundations of this phenomenon and made them understandable to practitioners, focusing on the implementation of socially responsible behavior. Davis also views a business organization as a company that brings together responsible people, including top managers, investors, shareholders, employees, and representatives of the local community. This company is responsible for meeting not only economic, but also environmental, social, political and other demands of society (Davis, 1960).

Kolot (2013) notes that the modern business organization is an organic part of a complex, interconnected, and interdependent set of institutions. The latter significantly affect its activities, acting as consumers, suppliers, authorities, NGOs, intermediaries, arbitrators and others. This complex interaction intertwines economic, social, environmental and political interests, motives and aspirations. Society is interested in each business structure gaining the status of an organization focused on socially responsible actions and balanced development. Both science and practice convince that only those organizations that are capable and ready to fulfill their moral and spiritual obligations and legal norms in the economic, social, environmental and other spheres, which are vital for economic development and society as a whole, can count on balanced development (Kolot, 2013). An important confirmation of the relevance of business organizations' social responsibility development, formed on the defining role of the social contract, is Carroll's model; he proposed to view corporate social responsibility as a product of economic, social and environmental expectations that the society directs to the company (Carroll, 2004). 
Sethi tried to link "corporate behavior" and social responsibility. He interprets social responsibility as the implementation of social obligations and a response to the challenges of the market environment and society (Sethi, 1975). A continuation of this idea were the approaches of Wartick and Cochran (1985), who defined the role of social responsibility as the necessary interaction of business with society for their own and joint progress. They develop Carroll's scientific ideas, significantly develop and modify them. While Carroll's model is driven by relevant social problems, Wartick and Cochran emphasize the need to develop projects to minimize the risks posed by the dynamic market environment and the behavior of key social actors (Wartick \& Cochran, 1985).

So, in order for business organization to improve socially responsible practices, it is necessary to develop and modernize social dialogue, which is a stimulating factor in the development of these processes.

In many countries, business structures play an active role in creating and improving government policy and regulation, in fact, the private sector to some extent performs traditional government functions. Corporations form new rules and principles of conduct for state and non-state structures both at the state and international levels. Most companies have changed their attitude towards interaction with the main players who represent a number of interests and requirements for the company on social and economic issues, protection of natural resources. Business structures implemented the issues of interaction with the main stakeholders in the system of organizational management, providing for an active and partner dialogue, improved and systematized approaches to solving problematic issues, established communication platforms for interaction.

In European countries, corporate social responsibility has long become an integral part of both supranational and national policies. In most European countries, governments, guided by the principles of the "welfare state," set standards for the protection of workers' rights, labor and environmental protection, social security, etc. (Social dialogue in Ukraine in the context of signing an association agreement challenges and proposals: draft, 2014). In Germany, business is actively developing the concept of social responsibility at the public level. The field of consulting services for German companies on ethics and morals is actively developing. An annual competition has been announced that provides an award from the Government for the most socially responsible company, the Arbeit Plus award (Deutsche Welle, n.d.). The French Parliament has passed a law on corporate social responsibility. According to its norms and regulations, leading French companies are obliged to provide decent working conditions, use natural resources responsibly, and promote the development of the social sphere (Deutsche Welle, n.d.). These examples demonstrate that many prominent economists call the European model of corporate social responsibility the corporate ability to respond socially (European Industrial Relations Observatory: CSR Basic Search Results, n.d.). Crane and Matten (2004) complement the characteristics of the European model of social responsibility: 1) the economic component of responsibility is characterized by special obligations to staff and local communities; 2) legal responsibility is the basis of socially responsible practices; and 3) business ethics is actively manifested in establishing relationships with key stakeholders (Crane \& Matten, 2004).

Since 2011, first, international and then domestic large companies in Ukraine began to actively use the idea of social responsibility, developing their models of socially responsible practices and ways to use them to strengthen competitiveness, improve their image and brand. But their active development and popularization are possible when the institutional environment is formed, which will encourage the development of new forms of socially responsible behavior and involve more and more business structures in this process. The development of social dialogue is a driving factor in the development of these processes, and its active development will accelerate the implementation of the values and basic principles of socially responsible behavior for businesses and other parties to social dialogue. This also contributes to sustainable and balanced social development based on social justice.

In this context, the experience of Wales deserves attention, where in 2015 a law on the welfare of future generations was passed. This legal act enshrines the principles that state bodies should be guided by when approving management decisions. 
The law introduces a special public position, the Commissioner for Future Generations, and sets out his responsibilities for sustainable development. The requirements for monitoring activities in this area (national indicators and approaches to their measurement, the procedure for compiling annual reports on the welfare and future development trends of the country, including requirements for the reports of ministers and heads of other state institutions on these issues) have been determined. Measures to be taken by public authorities to facilitate the achievement and promotion of the ideology of sustainable development in society have been identified. It is mandatory to prepare urban plans for sustainable development and involve the public in their formation and monitoring of implementation (Sustainable Development Goals).

The tool that should be used to form such an attitude of companies towards internal stakeholders is the participation of employees in the authorized capital, therefore, the receipt of shareholder income and representation in the governing bodies of corporations. This approach creates the prerequisites for increasing the interest of employees in the results of the organization's production activities, turns them from powerless cogs of someone else's mechanism into responsible subjects of socio-economic processes.

The state loses a number of opportunities when it ignores CSR and does not show its own active participation in the processes of forming a positive environment for socially responsible practices of business organizations, and this situation needs to be corrected.

\section{GENERALIZATION OF THE MAIN STATEMENTS}

To ensure high quality of social dialogue, it is necessary to strengthen the democratic participation of partners who have sufficient potential for effective and responsible participation in this process, as well as the strength and flexibility to adapt to modern conditions and seize new opportunities. Since in some countries, workers 'and employers' organizations do not have the capacity to engage in quality social dialogue, this does not contribute to the effectiveness of their participation in governance processes and the needs and interests of the parties they represent. In other countries, employment agencies often do not have sufficient political clout to influence key policy decisions; in third countries, the weakening of social dialogue institutions is motivated by the need to reduce labor costs and a sharp increase in competitiveness, which, in turn, seriously increases inequality and leads to a rapid decline in the number of collective agreements (Vaughan-Whitehead, 2016).

The realities of our time confirm the fact that other institutions and their infrastructure determine the agenda and expand the framework for organizing and conducting social dialogue at both the international and national levels. Of course, in such conditions, the concept of corporate social responsibility, which is now in a state of active institutionalization, can become, if not an alternative, then at least an additional mechanism of social regulation of labor relations and the search for a balance between the parties' interests. The concept of corporate social responsibility implies that companies voluntarily refuse to act solely in their own, narrowly focused financial interests and include the interests of other stakeholders in their strategy, including key internal stakeholders, namely personnel. Manifestations of social responsibility on the part of business entities positively affect the formation of a favorable environment for developing social dialogue, which, in turn, actively creates the conditions for improving socially responsible practices.

If at first it seemed that the concept of corporate social responsibility contradicted market logic and was based solely on the ethical readiness of management and owners for charity, then the further evolution of theory and practice has shown that its implementation is quite pragmatic and meets long-term interests of society and companies (Lydenberg, 2005).

To date, a number of concepts and approaches have been developed based on the idea that companies should take into account the interests not only of owners and management, but also of many other stakeholders. 
The vast majority of large companies, especially TNCs, not feeling the demands of the internal and external environment, do not want to share super-profits with employees, do not allow them to access the governing bodies of companies; with external stakeholders, they use socially irresponsible practices, because they take advantage of a monopoly in the market segment and the helplessness of actors who must influence their behavior. In this context, tariff agreements should not only provide the rules for employees' participation in the collegial governing bodies of companies, their supervisory boards, but also the obligation to include these rules in collective agreements, and in legislation - the responsibility of owners for violations and norms of industrial democracy.

In Ukraine, a significant part of business is almost not involved in the implementation of the concept of social responsibility. The main reason is the entrepreneurs' focus on achieving short-term results and a restrained attitude towards long-term social goals. This is primarily due to the instability of legislation, corruption in law enforcement, state bodies, and the judicial system. In conditions of volatility, frequent and too high volatility of the composition of officials, uncertainty about the future of the personnel of government and business, the motivation for establishing strong business partnerships between employers and government bodies is lost. Failure of the authorities to fulfill their obligations and decisions previously made by them and their predecessors, as well as uncertainty about the future, contribute to the formation of a psychology of political and material gain "here and now" in the authorities and business circles, and a disregard for moral values for the sake of the future. Given the lack of effective and sustainable institutions in Ukraine, a situation has emerged when both sides of the social dialogue are not interested in building relations based on mutual trust and mutual responsibility, in making longterm decisions.

\section{DISCUSSION}

The state and its institutions play a leading role in the development of social dialogue as an indisputable tool for increasing the social responsibility of business organizations, especially given the lack of experience of fruitful interaction between the parties to social dialogue, the current aggravation of socio-economic problems, and the growing distrust of official institutions in Ukrainian society. The role of the state should be manifested not in an attempt to dictate norms of behavior to other partners, but in the development of an active policy aimed at promoting partnership, ensuring modern social and labor relations, stimulating the development of the collective bargaining process, which will actively influence the acceleration of the spread of socially responsible practices in the private sector.

Another problem with the formation of social dialogue in Ukraine is that the government and employers violate the principles underlying any agreement, namely the obligation to abide by the agreements reached. Attempts by some public figures, especially trade union leaders, to rectify this situation by adopting legislation that should force the parties to social dialogue to strictly comply with the provisions of the agreements, do not correspond to the nature of social dialogue and its essence. First of all, an environment and an atmosphere of social responsibility should be formed here, which stimulates the parties to cooperate, in which both trade unions, the state and employers are interested. Such cooperation should be implemented on the basis of the parties' acceptance of certain self-restraints, the search for compromises and mutual concessions. Agreements should be perceived by all parties as a result of their activities that meet the criteria of the highest value. The desired behavior of partners can be expected only in response to their own actions, which are consistent with previous agreements, and the understanding that violation of the agreement by one party will cause an adequate reaction from others. Social dialogue as a prerequisite for a real increase in social responsibility of the main actors of socio-economic progress should develop along the trajectory: "social contacts - making socially responsible decisions - socially responsible actions." The result and criterion of its development should be not the number of contacts between the parties, but positive changes in the content of state socio-economic policy, the approximation of practice to the concept of decent work. However, in Ukraine, both the state em- 
ployers see the content of their social responsibility only in a periodic increase in wages. At the same time, it is not taken into account that an important characteristic of social responsibility is not small donations, but the provision of income, which creates conditions for employees to receive economic freedom and the opportunity to use the benefits of civilization for physical and spiritual development and recreation.

Most scholars believe that collective agreements, as a result of dialogue, actively influence the level of wages, raising them above the level formed in the labor market. This, in turn, contributes to reducing wage inequality, helps to maintain ag- gregate demand and provides the necessary economic basis for the activities of business organizations. Numerous studies by the International Labor Organization confirm the fact that the decline in the quality of collective bargaining and the reduction in the number of employees involved in these processes negatively affect citizens' confidence in public authorities. The level of social cohesion of society decreases, the number of unemployed increases, and workers' incomes decrease. Conversely, an increase in the number of collective agreements helps to reduce unemployment in the country, revive employment, and increase the effective demand of the population (International Labour Office, 2013).

Table 1. Collective agreements and the number of staff covered

Source: Compiled based on the data from the State Statistics Service of Ukraine.

\begin{tabular}{|c|c|c|c|c|}
\hline \multirow{2}{*}{ Economic activities } & \multirow{2}{*}{$\begin{array}{l}\text { Number of concluded } \\
\text { and registered collective } \\
\text { agreements, 2018, units }\end{array}$} & \multirow{2}{*}{$\begin{array}{l}\text { Number of concluded } \\
\text { and registered collective } \\
\text { agreements, 2019, units }\end{array}$} & \multicolumn{2}{|c|}{$\begin{array}{l}\text { Number of employees covered } \\
\text { by collective agreements }\end{array}$} \\
\hline & & & $\begin{array}{c}\text { Thousand } \\
\text { people, } 2018\end{array}$ & $\begin{array}{c}\text { Thousand } \\
\text { people, } 2019\end{array}$ \\
\hline \multirow{2}{*}{$\begin{array}{l}\text { Agriculture, forestry and fisheries, } \\
\text { including agriculture }\end{array}$} & 4295 & 3719 & 290,4 & 258,2 \\
\hline & 3687 & 3207 & 231,6 & 207,4 \\
\hline Industry & 5674 & 5506 & 1501,6 & 1467,9 \\
\hline Construction & 1281 & 1148 & 76,8 & 73,4 \\
\hline $\begin{array}{l}\text { Wholesale and retail trade; repair of } \\
\text { motor vehicles and motorcycles }\end{array}$ & 2405 & 1877 & 320,8 & 294,3 \\
\hline $\begin{array}{l}\text { Transport, warehousing, postal and } \\
\text { courier activities }\end{array}$ & 1712 & 1510 & 530,6 & 500,3 \\
\hline activities in the field of transport & 937 & 664 & 246,3 & 263,7 \\
\hline $\begin{array}{l}\text { warehousing and ancillary activities in } \\
\text { the field of transport }\end{array}$ & 937 & 795 & 214,5 & 172,7 \\
\hline postal and courier activities & 48 & 51 & 69,8 & 64,0 \\
\hline $\begin{array}{l}\text { Temporary accommodation and } \\
\text { catering }\end{array}$ & 330 & 341 & 22,4 & 20,9 \\
\hline Information and telecommunications & 541 & 436 & 65,2 & 59,6 \\
\hline Financial and insurance activities & 255 & 199 & 103,7 & 99,0 \\
\hline Real estate transactions & 968 & 855 & 32,2 & 29,4 \\
\hline \multirow{2}{*}{$\begin{array}{l}\text { Professional, scientific and technical } \\
\text { activities, including R\&D }\end{array}$} & 1911 & 1523 & 169,2 & 127,7 \\
\hline & 483 & 428 & 82,6 & 69,9 \\
\hline $\begin{array}{l}\text { Activities in the field of administrative } \\
\text { and support services }\end{array}$ & 1246 & 1191 & 89,1 & 90,6 \\
\hline $\begin{array}{l}\text { Public administration and defense; } \\
\text { compulsory social insurance }\end{array}$ & 8176 & 5059 & 386,2 & 309,3 \\
\hline Education & 23113 & 21565 & 1313,4 & 1253,0 \\
\hline \multirow{2}{*}{$\begin{array}{l}\text { Health care and social assistance, } \\
\text { including health care }\end{array}$} & 4482 & 3819 & 878,5 & 819,5 \\
\hline & 3189 & 2895 & 792,2 & 744,1 \\
\hline $\begin{array}{l}\text { Arts, sports, entertainment, and } \\
\text { recreation }\end{array}$ & 2908 & 2441 & 109,3 & 100,4 \\
\hline $\begin{array}{l}\text { including activities in the field of } \\
\text { creativity, arts and entertainment }\end{array}$ & 1853 & 1507 & 63,3 & 57,8 \\
\hline $\begin{array}{l}\text { the functioning of libraries, archives, } \\
\text { museums and other cultural } \\
\text { institutions }\end{array}$ & 684 & 661 & 33,7 & 31,3 \\
\hline Provision of other types of services & 325 & 219 & 10,2 & 8,4 \\
\hline
\end{tabular}


Table 1 shows the number of collective agreements concluded by type of economic activity in recent years in Ukraine and the number of employees covered.

The dynamics of concluding contracts shows a negative trend towards a decrease in their number in all spheres of economic activity by an average $15-20 \%$, as well as to a decrease in the number of staff covered by collective bargaining, which negatively affects the quality of their working life. The results of this analysis are a litmus test showing threatening trends both in the field of collective bargaining and in socio-economic processes in general. Therefore, first of all, to improve the quality of social dialogue, it is necessary to improve collective bargaining processes, which are an important consequence of socially responsible actions. This will positively affect both socio-economic processes in society and the institutional environment of the functional manifestation of social dialogue. The increase in the number of collective agreements concluded should be a positive and applied result of the institutional action of social dialogue and a powerful manifestation of socially responsible behavior of employers, which, in turn, will lay the foundations for socio-economic progress. But such results can be achieved if the main participants in this process pursue an active policy both in legislatively defined areas and in areas that are determined by the state of socio-economic processes and the development of social relations in general.
Modernization of social dialogue institutions, in particular legislation, is a priority for public authorities and other social partners. This approach will solve the problem of lack of proper regulation and will not allow the social partners to freely interpret the provisions of the law.

Involvement of all parties in the social dialogue in the negotiation process should take place in two directions: 1) ensuring the possibility of exercising the right to participate in the social dialogue of «non-representative» organizations by giving them the right to an advisory vote; and 2) expanding the circle of participants in social dialogue by involving the general public. NGOs cannot be an independent party to the social dialogue, therefore their participation is possible only within the framework of the activities of tripartite bodies, the rules of procedure of which should contain provisions that will provide such opportunities.

The implementation of these stages of reforming social dialogue will ensure: an increase in its status; expanding the subject and sphere of influence on social-labor and other social relations; ensuring effective control over the implementation of the decisions of the parties to the dialogue; taking into account the peculiarities of the socio-economic realities of the country; transparency of decision-making by social partners; elaboration of a consolidated position by the parties to the dialogue; strengthening socially responsible behavior of business organizations; approximation to the standards of such dialogue.

\section{CONCLUSION}

The purpose of this study was to systematize the existing experience of modernizing social dialogue in order to increase the social responsibility of business organizations in Ukraine and create prerequisites for its sustainable socio-economic development.

Modernization of social dialogue as a prerequisite for increasing the social responsibility of the government, employers' and workers' organizations should move towards involving representatives of non-standard forms of employment in this process and updating the subject field of dialogue. Representatives of small business owners and employees, self-employed citizens, labor migrants, domestic workers, freelancers, and other representatives of non-standard forms of employment should become real participants in the social dialogue. In view of the above, provisions should be included in the legislation providing for their participation in social dialogue bodies. The interests of employees and employers in social dialogue bodies can also be represented by specialists (lawyers, economists, engineers) authorized by the respective teams and communities. Increasing the social responsibility 
of all parties to the social dialogue should be aimed primarily at solving the shameful problem for a European country of almost complete shadowing of the employment sector; at increasing productivity and increasing its pay on this basis; involvement of employees in production management, their receipt of shareholder income, which will contribute to the innovative modernization of the economy, the development of human capital, and the fair distribution of the created national product.

\section{AUTHOR CONTRIBUTIONS}

Conceptualization: Halyna Lopushniak, Yurii Marshavin, Taras Kytsak.

Data curation: Halyna Lopushniak, Taras Kytsak, Yurii Nikitin.

Formal analysis: Taras Kytsak, Olena Iastremska.

Investigation: Halyna Lopushniak, Yurii Marshavin, Olena Iastremska.

Methodology: Halyna Lopushniak, Yurii Marshavin, Yurii Nikitin.

Project administration: Taras Kytsak.

Resources: Halyna Lopushniak, Yurii Marshavin, Olena Iastremska.

Supervision: Taras Kytsak.

Validation: Halyna Lopushniak, Yurii Nikitin.

Visualization: Halyna Lopushniak.

Writing - original draft: Halyna Lopushniak, Yurii Marshavin, Taras Kytsak, Olena Iastremska.

Writing - review \& editing: Halyna Lopushniak, Taras Kytsak, Olena Iastremska, Yurii Nikitin.

\section{REFERENCES}

1. Bowen, H. (1953). Social responsibilities of the businessman. N.Y.: Harper \& Row.

2. Carroll, A. B. (2004). Managing ethically with global stakeholders: A present and future challenge. Academy of Management Executive, 18(2), 118. Retrieved from https://www.jstor.org/ stable/4166070?seq=1

3. Civil Society Forum. (2014). Social dialogue in Ukraine in the context of signing an association agreement - challenges and proposals: draft. Kyiv. (In Ukrainian). Retrieved from https://bureau. in.ua/downloads/social-dialogue/ Ukraine.pdf

4. Consolidated versions of the Treaty on European Union and the Treaty on the Functioning of the European Union 2012/C $326 / 01$. Official Journal of the European Union. Retrieved from https://eur-lex.europa.eu/legalcontent/EN/TXT/?uri=celex\%3AC 2012\%2F326\%2F01

5. Crane, A., \& Matten, D. (2004). Business Ethics - a European Perspective (pp. 427-451). Oxford University Press. Retrieved from https://www.researchgate.net/ publication/235356495_Business_ Ethics_A_European_Perspective

6. Culpepper, P. D., \& Regan, A. (2014). Why Don't Governments Need Trade Unions Anymore? The Death of Social Pacts in Ireland and Italy. Socio-Economic Review, 12, 723-745. Retrieved from https://doi.org/10.1093/ser/ mwt028

7. Davis, K. (1960). Can business afford to ignore social responsibilities? California Management Review, 2(3). https://doi. org/10.2307\%2F41166246

8. Decent work country programme of Ukraine for 2016-2019. (2016). Retrieved from https://www.ilo. org/budapest/countries-covered/ ukraine/WCMS_467704/lang--en/ index.htm

9. Deutsche Welle. (n.d.). Retrieved from http://surl.li/iiyg

10. Doherty, M. (2011). The Crisis and Collapse of Social Partnership in Ireland. Transfer, 17(3), 371-375. https://doi.org/10.1177\%2F1024258911410803

11. European Industrial Relations Observatory: CSR Basic Search
Results. (n.d.). Retrieved from http://csdle.lex.unict.it/docs/ activities/European-Industrial-Relations-Observatory-EIRO/2300. aspx (accessed May 24, 2017).

12. Giddens, A. (1992). Stratifikatsiya i klassovaya struktura [Stratification and class structure]. Sotsis - Socis, 9-10. Retrieved from https://kiogmuis.ucoz.ru/Student/ stratifikacija_i_klassovaja_struktura.pdf

13. Gofman, A. B. (Tr). (2019). Sotciologiya Emilia Diurkgeima // Sotsiologiya. Yeyo predmet, metod, prednaznacheniye [Emile Durkheim's sociology // Sociology. Its subject, method, purpose] (4th ed.) (pp. 9-35). Moscow: Yurait.

14. Grant, W. (1996). Corporatism/ Council Oxford Dictionary of Politics (pp. 112-115). Oxford University press.

15. International Labour Office. (2013). Sotsialnyy dialog: Doklad VI Mezhdunarodnogo biuro truda na 102 sessii Mezhdunarodnoy konferentsii truda [Social Dialogue: Report of the VI International Labor Office to the $102^{\text {nd }}$ Session of the International Labor Conference] (117 p.). Geneva: ILO. (In 
Russian). Retrieved from https:// www.ilo.org/wcmsp5/groups/ public/---ed_norm/---relconf/ documents/meetingdocument/ wcms_205832.pdf

16. International Labour Office. (2013). Social Dialogue Interventions: What works and why? A synthesis review 2002-2012. Retrieved from https://www.ilo.org/wcmsp5/ groups/public/---ed_mas/--eval/documents/publication/ wcms_212381.pdf

17. Kolot, A. M. (2013). Korporatyvna sotsialna vidpovidalnist evoliutsiia ta rozvytok teoretychnykh pohliadiv [Corporate social responsibility: evolution and development of theoretical views]. Ekonomichna teoriia - Economic theory, 4, 5-26. Retrieved from http://nbuv.gov.ua/UJRN/ ecte_2013_4_2

18. Kolot, A., Kozmenko, S., Herasymenko, O., \& Štreimikienè, D. (2020). Development of a decent work institute as a social quality imperative: Lessons for Ukraine. Economics and Sociology, 13(2), 70-85 https://doi.org/10.14254/2071789X.2020/13-2/5

19. Kolot, A. M. (2013). Sotsialnyi dialoh yak instytut pidvyshchennia sotsialnoi vidpovidalnosti [Social dialog as an institution to increase social responsibility]. Rynok pratsi ta zainiatist naselennia - Labor market and employment, 1, 21-24. Retrieved from http://nbuv.gov.ua/UJRN/ rpzn_2013_1_7

20. Lydenberg, S. D. (2005). Corporations and the Public Interest: Guiding the Invisible Hand (192 p.). San Francisco. Retrieved from https://www.amazon. com/Corporations-PublicInterest-Guiding-Invisible/ $\mathrm{dp} / 1576752917$

21. Petroie, O. M. (2013). Sotsialnyi dialoh yak instytut derzhavnoho upravlinnia [Social dialog as an institution of public administration] (84 p.). Kyiv: NADU.

22. Robotodavets. (n.d.). Website. Retrieved from http://surl.li/ inpd

23. Sapir, A. (2002). Globalisation and the reform of European Social Models. Journal of Common Market Studies, 44(2), 369-390. Retrieved from https://graspe. eu/SapirPaper.pdf

24. Sethi, S. P. (1975). Dimensions of corporate social performance an analytical framework. California Management Review, 17(3), 58-64. https://doi. org/10.2307\%2F41162149

25. Social dialogue. Report. (2013) The 102nd session of the International Labour Conference.

26. Social dialogue and tripartism. (2016, November 21). Retrieved from https://www.ilo.org/global/ topics/workers-and-employers-organizations-tripartism-and-socialdialogue/lang--en/index.htm

27. Sustainable development goals (17 goals for change in our world). In Strengthening the role of business in achieving CRS in Ukraine. (70 p.). (In Ukrainian). Retrieved from https://www.me.gov.ua

28. The Verkhovna Rada of Ukraine. (n.d.). Pro sotsialnyi dialoh $v$ Ukraini: Zakon Ukrainy vid 23 hrudnia 2010 r. № 2862-VI [On social dialogue in Ukraine: Law of Ukraine no. 2862-VI of Decemdber 23, 2010. Retrieved from http:// zakon1.rada.gov.ua/laws/show

29. Vaughan-Whitehead, D. (Ed.) (2016). Curbing Inequalities in Europe - How Can Social Dialogue and Industrial Relations Help to Close the Gap? Geneva: ILO. Retrieved from https://www.ilo. org/wcmsp5/groups/public/--ed_protect/---protrav/---travail/ documents/meetingdocument/ wcms_544236.pdf

30. Verner, I. Ye. (Ed.). (2019). Statystychnyi shchorichnyk Ukrainy za 2018 rik [Statistical yearbook of Ukraine for 2018] (481 p.). Kyiv: State Statistics Service.

31. Wartick, S. L., \& Cochran, P. L. (1985). The evolution of the corporate social performance model. Academy of Management Review, 10(4), 758. https://doi. org/10.2307/258044 